\title{
Experimental induction of gill disease in Atlantic salmon Salmo salar smolts with Tenacibaculum maritimum
}

\author{
Mark Powell ${ }^{1, *}$, Jeremy Carson ${ }^{2}$, Rebecca van Gelderen ${ }^{1}$ \\ ${ }^{1}$ School of Aquaculture, Tasmanian Aquaculture and Fisheries Institute, University of Tasmania, \\ Locked Bag 1370 Launceston, Tasmania 7250, Australia \\ ${ }^{2}$ Fish Health Unit, Tasmanian Aquaculture and Fisheries Institute, Department of Primary Industries, \\ Water and Environment, PO Box 46, Kings Meadows, Tasmania 7249, Australia
}

\begin{abstract}
An experimentally induced bacterial infection of marine Atlantic salmon Salmo salar smolt gills was developed using strains of Tenacibaculum maritimum originally isolated from disease outbreaks in Tasmania. The gills of salmon were inoculated with a high concentration of bacteria (4 $\times 10^{11}$ cells per fish) of either strain 00/3280 or 89/4747 T. maritimum. Gentle abrasion of the gills was used to enhance the progression of gill disease. One strain (00/3280) was highly pathogenic, causing morbidity and mortality within $24 \mathrm{~h}$ post-inoculation, and produced acute focal branchial necrosis associated with significant increases in plasma osmolality and lactate concentration compared with controls (non-inoculated) or strain 89/4747-inoculated fish. There were no differences in the whole body net ammonium flux between control (non-inoculated) and strain 00/3820-inoculated fish. Gill abrasion resulted in acute telangiectasis and focal lamellar hyperplasia in all fish regardless of bacterial inoculation. This work provides the basis of a challenge model suitable for investigating the pathophysiological processes associated with acute branchial necrosis in marine fish, suggesting that osmoregulatory and possibly respiratory dysfunction are the primary consequences of infection.
\end{abstract}

KEY WORDS: Atlantic salmon · Tenacibaculum maritimum · Pathophysiology · Gill disease · Osmoregulation $\cdot$ Respiration

\section{INTRODUCTION}

Bacterial diseases of freshwater fish epithelia have been extensively studied with the primary focus upon bacteria from the Cytophagales, such as bacterial gill disease caused by Flavobacterium branchiophilum (Ostland et al. 1994, 1995), and necrotizing skin diseases such as columnaris disease caused by F. columnare (Thomas-Jinu \& Goodwin 2004) and bacterial cold-water disease caused by F. psychrophilum (Cipriano et al. 1996 and review by Nematollahi et al. 2003). However, in marine fishes relatively few bacterial skin and gill diseases have been characterised. Tenacibaculum maritimum (formerly Flexibacter maritimus) has been reported to cause significant skin and gill pathology in a wide variety of species including red seabream Pagrus major, black seabream Acanthopa- grus schegeli, rock bream Oplegnathus fasciatus, Japanese flounder Paralichthys olivaceus (Baxa et al. 1986, Wakabayashi et al. 1986), Dover sole Solea solea (Bernardet et al. 1990), turbot Scophthalmus maximus (Alsina \& Blanch 1993), Atlantic salmon Salmo salar, rainbow trout Onchorynchus mykiss, striped trumpeter Latris lineata and greenback flounder Rhombosolea tapirina (Handlinger et al. 1997). Although primarily a skin infection causing ulcerative dermatitis (Handlinger et al. 1997), gill infections where a necrotizing branchitis occurs are not uncommon (Handlinger et al. 1997).

The aim of this research was to investigate whether experimental inoculation of the gills of Atlantic salmon with Tenacibaculum maritimum could cause acute gill disease and to identify potential processes that may be responsible for mortality. 


\section{MATERIALS AND METHODS}

Preparation of bacterial cultures. Cultures of Tenacibaculum maritimum were isolated by the Department of Primary Industry, Water and Environment from the skin of farmed salmon from Tasmania, Australia, with clinical cases of cutaneous erosion disease. The cultures were designated 89/4747 (Atlantic salmon) and 00/3280 (rainbow trout) and were isolated in 1989 and 2000 respectively. The bacteria were isolated on the medium of Anacker \& Ordal (1959), formulated with seawater. Isolates were identified using a $16 \mathrm{~S}$ ribosomal RNA (rRNA) PCR primer set specific for T. maritimum (Carson 1998). Cultures were stored frozen at $-80^{\circ} \mathrm{C}$ on MicroBank beads (Pro-Lab Diagnostics) until required.

Cultures for infection trials were prepared by inoculating $200 \mathrm{ml}$ of Shieh's medium (Song et al. 1988) formulated with seawater (mineral salts buffer, MSB) in a 11 conical flask and incubated with gentle agitation $\left(30\right.$ cycles $\mathrm{min}^{-1}$ ) at 20 to $22^{\circ} \mathrm{C}$ for $48 \mathrm{~h}$. The cell suspension was harvested by centrifugation at $2500 \mu \mathrm{g}$ RCF (relative centrifugal force) for $20 \mathrm{~min}$ and the pellet washed twice with sterile seawater. Harvested cells were resuspended in $15 \mathrm{ml}$ of sterile seawater.

Experimental series 1: Infection study. Atlantic salmon smolts of mean mass $( \pm$ SE) $77.0 \pm 2.9 \mathrm{~g}$ were acclimated to full strength seawater (35 ppt) over a period of $10 \mathrm{~d}$, then allocated to triplicate tanks (4 fish per tank, $\mathrm{n}=12$ per treatment) and allowed to habituate for $24 \mathrm{~h}$ prior to anaesthetization with AQUI-S $\left(0.04 \mathrm{ml} \mathrm{l}^{-1}\right)$ or clove oil $\left(0.03 \mathrm{ml} \mathrm{l}^{-1}\right)$. The gill arches were then separated and all of the filaments abraded by stroking gently with a blunt spatula. Aliquots $(0.5 \mathrm{ml})$ of Tenacibaculum maritimum culture in sterile, filtered seawater were applied to the gill arches on each side of the fish (total $1 \mathrm{ml}$ T. maritimum culture, $4 \times 10^{11}$ cells per fish, $\mathrm{n}=12$ per treatment). Controls consisted of fish that were inoculated with filtered seawater only $(\mathrm{n}=12$, repeated twice). An additional group of fish was inoculated with $1 \mathrm{ml}$ of T. maritimum (strain 00/3280) culture onto the gills without prior filament separation or abrasion. Fish were allowed to recover in their respective tanks and monitored over the subsequent $5 \mathrm{~d}$. Moribund fish were removed and cultures made from the gills on Shieh's agar (Song et al. 1988) formulated with seawater mineral salts agar (MSA), and colonies were confirmed as T. maritimum by colony colour and shape, as well as indirect fluorescent antibody test (IFAT) using a rabbit antibody prepared with a whole cell formalin-inactivated cell suspension of $T$. maritimum 89/0235 (rainbow trout).

Experimental series 2: Comparative pathology of Tenacibaculum maritimum strains. In Experimental series 1 there was an apparent difference in the pathogenicity of the 2 strains of $T$. maritimum used. Thus, it was decided to further examine the effects of acute exposure of smolts to the 2 different strains.

Seawater-acclimated Atlantic salmon smolts were allocated to 301 round tanks (6 fish per tank, 3 tanks per treatment) following anaesthesia, gill abrasion and inoculation with either strain $89 / 4747$ or $00 / 3280$ of Tenacibaculum maritimum. Controls consisted of fish that had the gill filaments separated but were inoculated with seawater. Fish were allowed to recover and maintained in static aerated seawater at 17.8 to $18.4^{\circ} \mathrm{C}$ (Fig. $1 \mathrm{~A}$ ), 79 to $95 \% \mathrm{O}_{2}$ saturation (Fig. 1B) for $24 \mathrm{~h}$ post-inoculation. Total ammonium concentrations were measured using the method of Verdouw et al. (1978). During the exposure, mori-
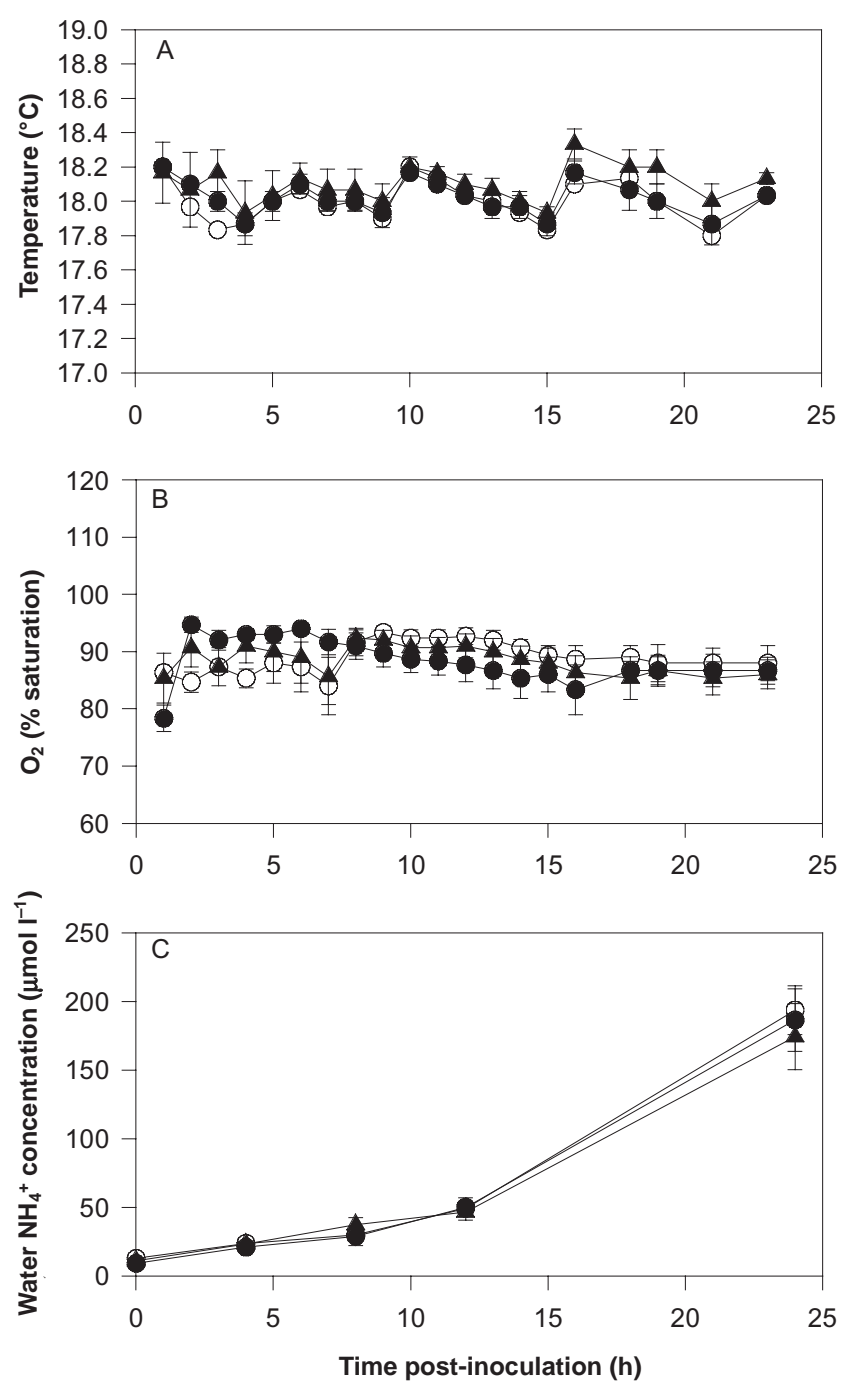

Fig. 1. (A) Mean $( \pm \mathrm{SE})$ temperature, (B) oxygen saturation and $(\mathrm{C})$ water ammonium concentration for tanks containing Atlantic salmon Salmo salar smolts experimentally inoculated

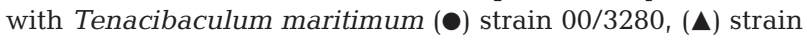
$89 / 4747$ or $(\mathrm{O})$ controls over a $24 \mathrm{~h}$ static challenge 
bund fish (unresponsive to touch) were removed, anaesthetised with $0.04 \mathrm{ml} \mathrm{l}^{-1}$ clove oil and bled from the caudal vein. Heparinised blood (100 IU ammonium heparin, Sigma-Aldrich) was then centrifuged at $8000 \times g$, the plasma decanted and frozen at $-20^{\circ} \mathrm{C}$ for further analysis. The gills were swabbed onto MSA for confirmation of the presence of $T$. maritimum using colony morphology and IFAT. The gills were then removed and fixed in seawater Davidson's solution for histological examination. After $24 \mathrm{~h}$ of exposure, surviving fish were killed by anaesthetic overdose (clove oil $>0.03 \mathrm{ml} \mathrm{l}^{-1}$ ) and sampled as for moribund fish.

Plasma osmolality was determined using a Vapro 5520 vapour pressure osmometer (Wescor). Plasma chloride was determined according to the method of Zall et al. (1956) and plasma lactate concentrations were determined using a commercial lactate assay kit (Sigma Diagnostics, protocol 735). Gills were embedded in paraffin wax, sectioned at $5 \mu \mathrm{m}$ and stained with haematoxylin and eosin.

Experimental series 3: Effects of Tenacibaculum maritimum infection on ammonium flux. In Experimental series 2, despite the removal of moribund fish inoculated with T. maritimum strain 00/3280, the total ammonium concentrations in the water remained equivalent to that of fully stocked tanks that experienced no morbidity (T. maritimum strain 89/4747 and control tanks). Therefore, the net ammonium flux was measured for fish inoculated with T. maritimum strain 00/3280 and controls.

The gills of seawater-acclimated smolts were abraded and inoculated as described above with either strain 00/3280 or seawater (controls), and placed into individual black acrylic flux chambers (internal volume of 1 l) supplied with flowing seawater and constant aeration (1 fish per chamber, 9 fish per treatment). Following $24 \mathrm{~h}$ of recovery, the flow to the flux chambers was stopped and a water sample $(5 \mathrm{ml})$ removed and immediately frozen $\left(-20^{\circ} \mathrm{C}\right)$ for later analysis. Following a $3 \mathrm{~h}$ period, a second water sample was removed and similarly frozen, after which the water flow to each flux chamber was reinstated. Fish were then removed, killed by anaesthetic overdose (clove oil $>0.03 \mathrm{ml} \mathrm{l}^{-1}$ ) and the gills swabbed onto MSA for subsequent confirmation of the presence/absence of Tenacibaculum maritimum using colony morphology and IFAT.

Plasma osmolality, chloride concentrations and lactate concentrations were compared statistically between strains (00/3280 and 89/4747) and controls using analysis of variance with a Bonferroni corrected $t$-test planned contrast relative to controls. $p$ values of less than 0.05 were considered to be significant.

Water samples were analysed for total ammonium concentration using the method of Verdouw et al.
(1978). Whole body net ammonium flux was then calculated according to:

$$
J_{\text {net }} \mathrm{NH}_{4}^{+}=\frac{\left[\mathrm{NH}_{4}^{+}\right]_{t=1}-\left[\mathrm{NH}_{4}^{+}\right]_{t=0}{ }^{*} V}{M^{*} T}
$$

Where $\left[\mathrm{NH}_{4}^{+}\right]_{t=\mathrm{x}}$ is the concentration of total ammonium $\left(\mathrm{mmol} \mathrm{l}^{-1}\right)$ in the water sample at the start or end of the flux period, $V$ is the volume of the flux chamber, $M$ is the mass of the fish $(g)$ and $T$ is the duration of the flux period (h). Net whole body ammonium fluxes were compared with zero and between inoculated and control fish using a $t$-test. $\mathrm{p}$ values of less than 0.05 were considered to be significant.

\section{RESULTS}

\section{Experimental series 1: Infection study}

The highest rate of mortality (70\%) occurred within $48 \mathrm{~h}$ post-inoculation in fish that had received gill abrasion and infection with strain 00/3280 (Fig. 2). Fish with non-abraded gills inoculated with strain 00/3280 had a maximum mortality rate of $50 \%$ at $96 \mathrm{~h}$, whereas fish inoculated with strain 89/4747 and controls had

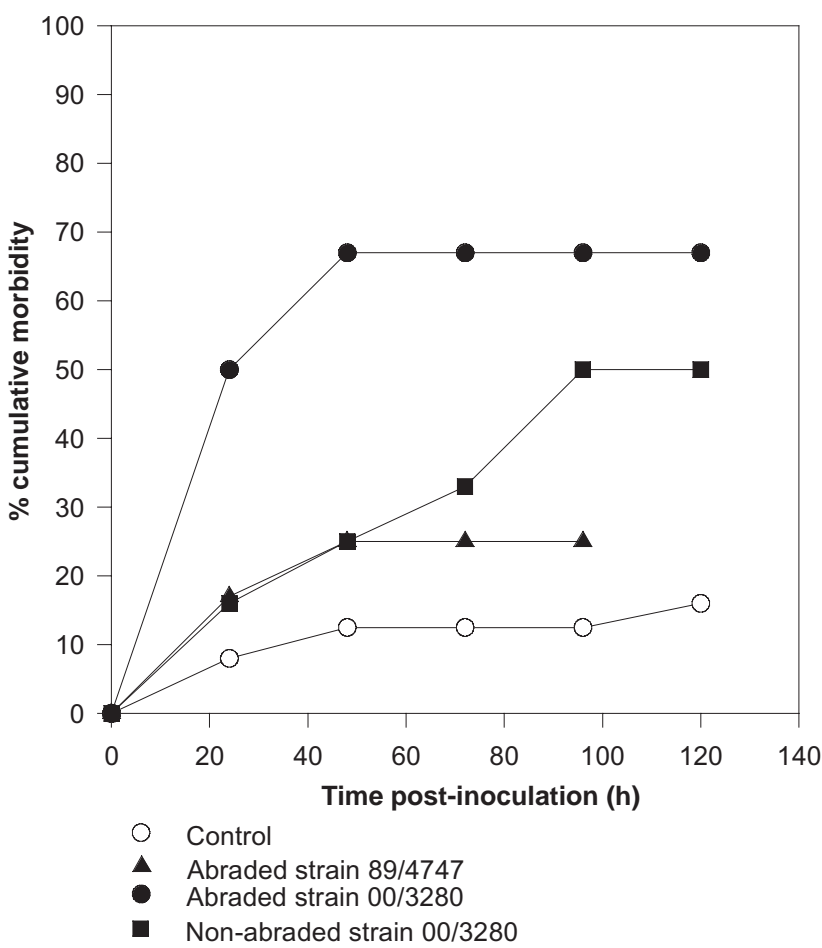

Fig. 2. Salmo salar infected with Tenacibaculum maritimum. Percent cumulative mortality of Atlantic salmon smolts experimentally inoculated with (๑) strain 00/3280 following a light

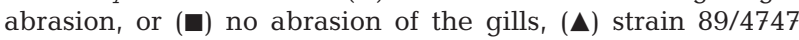
following light abrasion or $(\mathrm{O})$ controls (light abrasion, no bacteria) 
maximum mortality rates of 25 and $11 \%$ at $48 \mathrm{~h}$ respectively (Fig. 2). Bacterial colonies with characteristics typical of Tenacibaculum maritimum were isolated from all fish within those groups inoculated with bacteria. The 00/3280-inoculated fish returned heavy bacterial growth from gill smears compared with the light bacterial growth from gill smears of control (noninoculated) fish (Table 1).

\section{Experimental series 2 and 3: Comparative pathology and ammonium flux experiments}

Fish inoculated with strain 00/3280 showed a higher rate of morbidity than fish treated with strain 89/4747 or controls over the $24 \mathrm{~h}$ challenge experiment (Fig. 3A). There was heavy bacterial growth from gill smears of fish inoculated with Tenacibaculum maritimum bacteria (both strains 00/3280 and 89/4747) and poor growth from smears taken from control fish (Table 1). Bacteria isolated from fish inoculated with strain 00/3280 returned a positive result when tested with IFAT, while bacterial smears from fish inoculated with strain 89/4747 and control fish were negative (Table 1). Water ammonium concentrations increased in all tanks over the exposure duration; however, levels remained below $200 \mu \mathrm{mol} \mathrm{l}^{-1}$ (Fig. 1C). Moribund fish from the strain 00/3280 groups had significantly higher plasma osmolality than fish that had been inoculated with strain $89 / 4747$ or control animals at $24 \mathrm{~h}$ post-inoculation $\left(F_{2,19}=8.61, \mathrm{p}=0.0022\right)$ (Fig. 3B). However, there were no significant differences in the plasma $\mathrm{Cl}^{-}$concentration between the groups $\left(F_{2,19}=2.99, \mathrm{p}=0.0742\right)$ (Fig. 3C). There were significantly elevated plasma lactate concentrations in moribund fish inoculated with strain 00/3280 compared with either strain 89/4747-inoculated or control fish after $24 \mathrm{~h}$ of exposure $\left(F_{2,19}=6.24, \mathrm{p}=0.0082\right)$

Table 1. Tenacibaculum maritimum infecting Salmo salar. Recovery of bacteria from gills following experimental inoculation and indirect fluorescent antibody test (IFAT) confirmation. ND = not determined; $-=$ no growth $/$ negative; $+/-=$ inconclusive $;+=$ poor growth/positive $;++=$ moderate growth $;+++=$ heavy growth

\begin{tabular}{|lcccc|}
\hline T. maritimum strain & $\begin{array}{r}00 / 3280 \\
\text { Scraped }\end{array}$ & $\begin{array}{c}00 / 3280 \\
\text { Non-Scraped }\end{array}$ & $\begin{array}{c}89 / 4747 \\
\text { Scraped }\end{array}$ & Control \\
\hline $\begin{array}{l}\text { Expt 1: Infection study } \\
\text { Culture }\end{array}$ & +++ & +++ & ++ & + \\
$\begin{array}{l}\text { Expt 2: Comparative pathology } \\
\text { Culture }\end{array}$ & +++ & ND & +++ & + \\
iFAT & + & ND & - & $+/-$ \\
Expt 3: Ammonium flux & +++ & ND & ND & - \\
\hline
\end{tabular}

(Fig. 3D). There was a significant negative net whole body ammonium flux in both control and strain 00/3280-inoculated fish. However, there was no significant difference in the magnitude of the net ammonium flux between control and strain 00/3280inoculated fish $\left(t_{31}=1.47, \mathrm{p}=0.1508\right)$ (Fig. 3E). Smears from fish inoculated with strain 00/3280 showed heavy growth of bacteria typical of $T$. maritimum, whereas control (non-inoculated) fish showed no bacterial growth (Table 1).

\section{Histopathology}

Morbid salmon inoculated with strain 00/3280 but not 89/4747 exhibited gills with yellowish mucoid aggregations at the filament tips. Histologically, there was focal epithelial necrosis with extensive bacterial mats overlaying necrotic tissue (Fig. 4A,B). Bacterial associated necrosis of the filaments occurred in what appeared to be a distal to proximal direction. There was very limited (only seen in 1 fish out of 6 examined) evidence of bacterial associated necrosis with strain 89/4747 and no necrosis in control (non-inoculated) gills (Fig. 4C). Abraded gills often showed signs of telangiectasis and congestion, irrespective of whether fish were inoculated with Tenacibaculum maritimum (Fig. 4E,F).

\section{DISCUSSION}

Gill abrasion enhances the susceptibility of catfish Ictalurus punctatus to infection with Flavobacterium columnare (Bader et al. 2003) and has been used to enhance the reliability of Tenacibaculum maritimum challenge in salmonids (J. Carson pers. comm.). In our study, abrasion enhanced the severity and rate at which the disease progressed leading to mortality. There were, however, clear differences in the susceptibility of fish to different strains of T. maritimum. Strain 00/3280 was pathogenic, whereas strain $89 / 4747$ was not. Indeed, strain 89/4747 failed to be detectable with IFAT. Failure or ambiguity of IFAT techniques have been reported with F. psychrophilum (Vatos et al. 2002). Both this species and its warm water counter-part F. columnare have a highly labile glycocalyx responsible for adhesion (Nematollahi et al. 2003) and F. columnare is also associated with chondroitinase (AC lyase) activity (Stringer-Roth et al. 2002). 
Apart from the glycocalix, F. columnare adherence to gill tissue is also dependent upon the presence of Dglucose or N-acetyl-D-glucosamine (Decostere et al. 1999). It is possible that the requirements of strain 89/4747 T. maritimum for adherence to gills were not fully met because of the cellular microclimate of the salmon gill. Failure to detect strain 89/4747 T. maritimum using IFAT may also reflect a difference in the bacterial glycocalyx of this strain compared with the pathogenic strain 00/3280.

The branchial epithelial necrosis caused by strain 00/3280, and less so with strain 89/4747 Tenacibaculum maritimum infection was similar to that reported by Handlinger et al. (1997) for naturally infected Atlantic salmon and rainbow trout. However, in our study, telangiectasis and focal hyperplasia of the branchial epithelium due to gill abrasion was common in control fish (non-inoculated) and fish inoculated with both strains of $T$. maritimum. Interestingly, the hyperplastic lesions on the gills were similar to those seen with amoebic gill disease, but with the difference that gill abrasion lesions were associated with telangiectasis, not parasome-containing amoebal trophozoites (Adams \& Nowak 2001, 2003). It appears that the branchial necrosis causes a strong osmoregulatory disturbance in Atlantic salmon with significant increases in plasma osmolality. This osmoregulatory disturbance probably involves ionoregulatory dysfunction. Although the mean plasma chloride concentrations were elevated in moribund salmon inoculated with strain 00/3280, this was not statistically different from controls. In other situations where extensive branchial necrosis occurs, such as oxidative injury, similar osmoregulatory disturbances may be present without any clear changes in plasma chloride levels (Powell \& Harris 2004). Similarly, reductions in plasma osmolality have been reported with experimental Flavobacterium branchiophilum infections of freshwater rainbow trout, although these were in association with a reduction in plasma elec- trolytes including chloride (Byrne et al. 1995). Plasma lactate concentrations were clearly elevated in moribund salmon suggesting that acute respiratory failure may occur pre-mortem. It is not clear whether the probable limited oxygen transfer was due to diffusive limitations in the gill or reduced perfusion of the gill. Byrne et al $(1991,1995)$ did not demonstrate any reduction in blood $\mathrm{pO}_{2}$ in freshwater brook trout Salvelinus fontinalis and rainbow trout experimentally infected with $F$. branchiophilum. However, Foscarini (1989) demonstrated a transient bradycardia and an acute branchial hyperplasia and oedema in $F$.

\section{4h Comparative pathology}
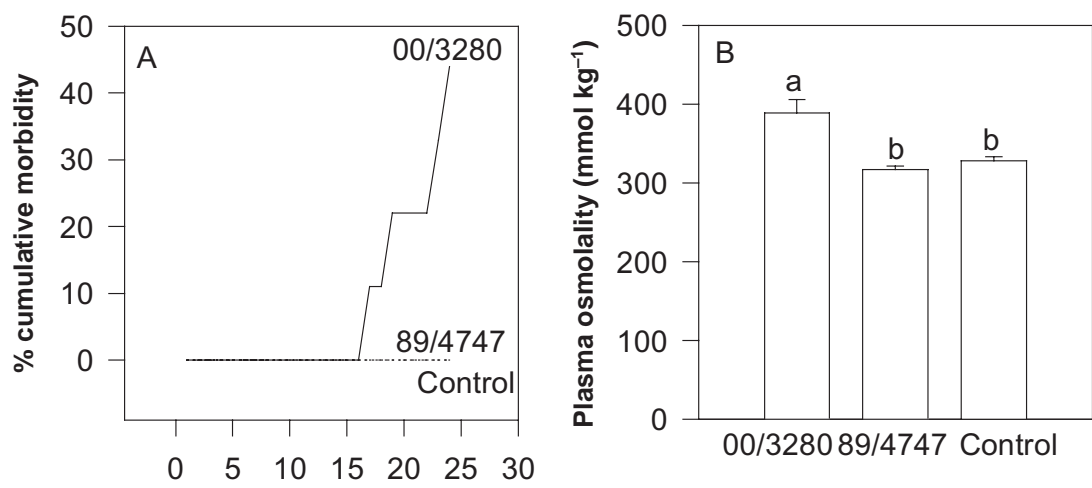

Time post-inoculation (h)
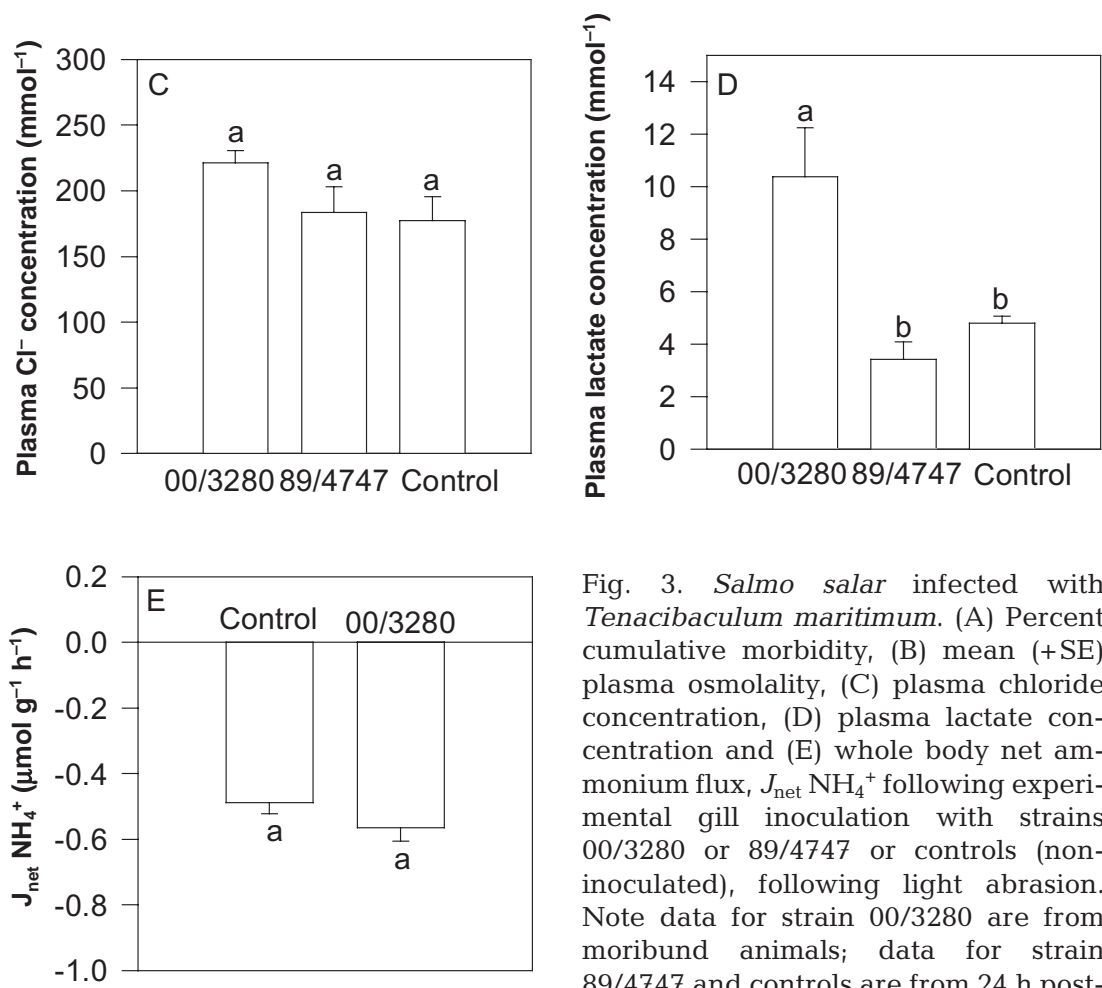

Fig. 3. Salmo salar infected with Tenacibaculum maritimum. (A) Percent cumulative morbidity, (B) mean $(+\mathrm{SE})$ plasma osmolality, (C) plasma chloride concentration, (D) plasma lactate concentration and (E) whole body net ammonium flux, $J_{\text {net }} \mathrm{NH}_{4}{ }^{+}$following experimental gill inoculation with strains $00 / 3280$ or $89 / 4747$ or controls (noninoculated), following light abrasion. Note data for strain 00/3280 are from moribund animals; data for strain $89 / 4747$ and controls are from $24 \mathrm{~h}$ postinoculation. Different letters indicate statistical significance 
columnaris (now F. columnare)-exposed eel Anguilla japonica. It is, therefore, not possible to exclude either diffusive or perfusive limitations to gas exchange as a cause of plasma lactate elevations in $T$. maritimum-infected salmon.

Despite the apparent deterioration in water quality, even with declining fish density, in the $24 \mathrm{~h}$ comparative pathology trial of fish inoculated with strain 00/3280, there were no significant differences in the rate of ammonium efflux. Increased ammonium effluxes have been reported in response to acute freshwater exposures of Atlantic salmon affected by amoebic gill disease (Roberts \& Powell 2003). Similarly rainbow trout experimentally infected with Flavobacterium branchiophilum had elevated plasma ammonium tensions (Byrne et al. 1995). It would appear that in acute Tenacibaculum maritimum infection of salmon, ammonium excretion rates are not significantly affected.

In conclusion, we have demonstrated that direct inoculation of high concentrations of Tenacibaculum maritimum directly onto the gills of Atlantic salmon smolts will induce a necrotic branchitis which appears to be enhanced by prior abrasion of the gill epithelium. Progression of the infection results in an acute and ultimately lethal osmoregulatory and potentially respiratory dysfunction.

Acknowledgements. Funding was provided from an Australian Research Council Large Research Grant to M.P.
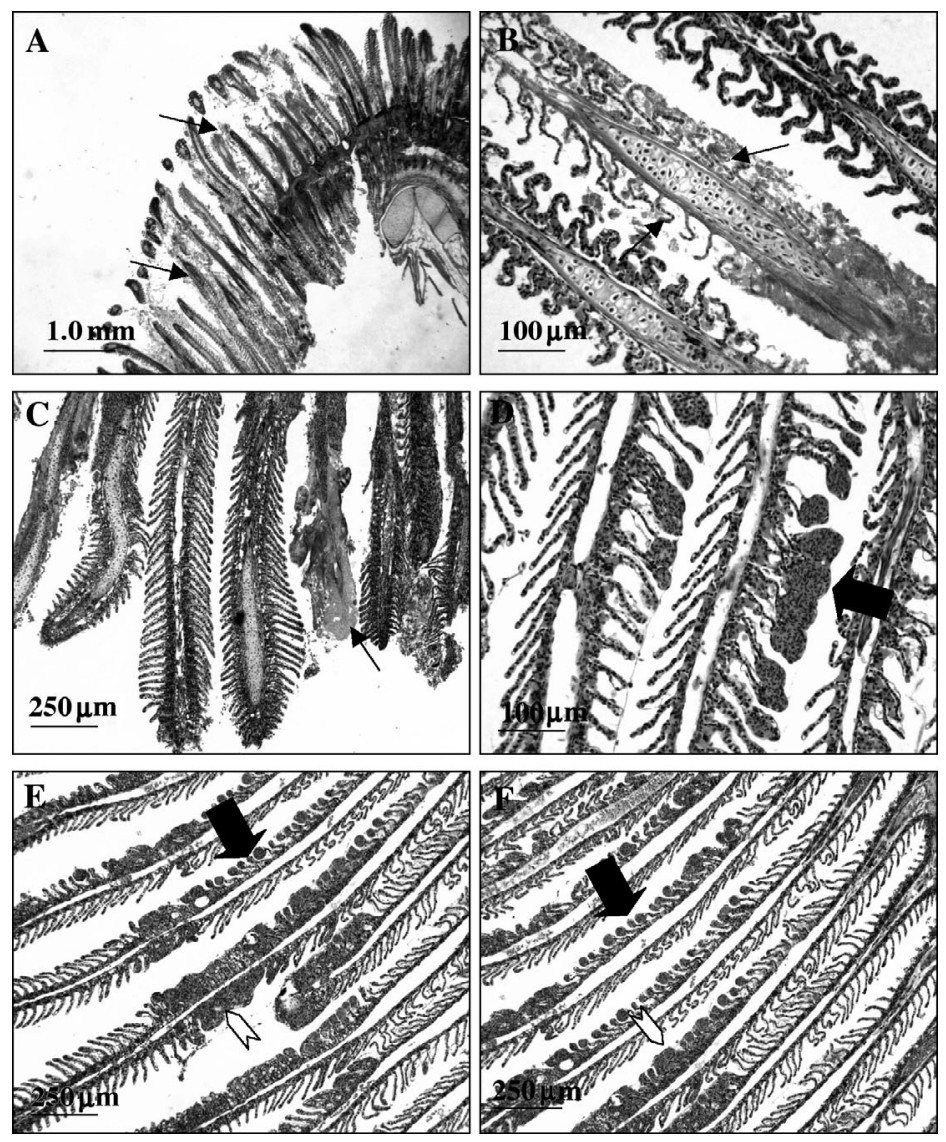

Fig. 4. Salmo salar infected with Tenacibaculum maritimum. (A,B) Extensive branchial necrosis associated with filamentous bacterial mats (arrows) on the gills of Atlantic salmon smolts inoculated with strain 00/3280. (C) Filamental necrosis associated with filamentous bacteria on the gills of salmon inoculated with T. maritimum strain 89/4747. (D) Telangiectasis (large black arrow) associated with the gills of control, (E) strain 00/3280-inoculated and (F) strain 89/4747-inoculated fish. Note the hyperplastic lesions also associated with gill abrasion (white arrow)

\section{LITERATURE CITED}

Adams MB, Nowak BF (2001) Distribution and structure of the lesions in the gills of Atlantic salmon, Salmo salar L., affected with amoebic gill disease. J Fish Dis 24:535-542

Adams MB, Nowak BF (2003) Amoebic gill disease: sequential pathology in cultured Atlantic salmon, Salmo salar L. J Fish Dis 26:601-614

Alsina M, Blanch AR (1993) First isolation of Flexibacter maritimus from cultivated turbot, Scophthamus maximus. Bull Eur Assoc Fish Pathol 13:157-160

Anacker RL, Ordal EJ (1959) Studies on the myxobacterium Chondorcoccus columnaris. 1. Serological typing. J Bacteriol 78:25-32

Bader JA, Nusbaum KE, Shoemaker CA (2003) Comparative challenge model of Flavobacterium columnare using abraded and unabraded channel catfish, Ictalurus punctatus (Rafinesque). J Fish Dis 26:461-467

Baxa DV, Kawai K, Kusuda R (1986 Characteristics of gliding bacteria isolated from diseased cultured flounder, Paralichthys olivaceus. Fish Pathol 21:251-258

Bernardet JF, Campbell AC, Buswell JA (1990) Flexibacter maritimus is the agent of 'black patch necrosis' in Dover sole in Scotland. Dis Aquat Org 8:233-237

Byrne PJ, Ferguson HW, Lumsden JS, Ostland VE (1991) Blood chemistry of bacterial gill disease in brook trout Salvelinus fontinalis. Dis Aquat Org 10:1-6

Byrne PJ, Ostland VE, Lumsden JS, MacPhee, DD Ferguson HW (1995) Blood chemistry and acid-base balance in rainbow trout Oncorhynchus mykiss with experimentallyinduced acute bacterial gill disease. Fish Physiol Biochem 14:509-518

Carson J (1998) Development of molecular probes for use in bacterial disease diagnosis and health monitoring of farmed and wild finfish in Australia. Final report on Project 93/128. Fisheries Research and Development Corporation, Canberra

Cipriano RC, Schill WB, Teska JD, Ford LA (1996) Epizootiological study of bacterial cold-water disease in Pacific salmon and further characterization of the etiological agent, Flexibacter psychrophila. J Aquat Anim Health 8: 28-36 
Decostere A, Haesebrouck F, Van Driessche E, Charlier G, Ducatelle R (1999). Characterization of the adhesion of Flavobacterium columnare (Flexibacter columnaris) to gill tissue. J Fish Dis 22:465-474

Foscarini R (1989) Induction and development of bacterial gill disease in the eel (Anguilla japonica) experimentally infected with Flexibacter columnaris: pathological changes in the gill vascular structure and in cardiac performance. Aquaculture 78:1-20

Handlinger J, Soltani M, Percival S (1997) The pathology of Flexibacter martimus in aquaculture species in Tasmania, Australia. J Fish Dis 20:159-168

Nematollahi A, Decostere A, Pasmans F, Haesebrouck F (2003) Flavobacterium psychrophilum infections in salmonid fish. J Fish Dis 26:563-574

Ostland VE, Lumsden JS, MacPhee DD, Ferguson HW (1994) Characteristics of Flavobacterioum branchiophilum, the cause of salmonid bacterial gill disease in Ontario. J Aquat Anim Health 6:13-26

Ostland VE, MacPhee DD, Lumsden JS, Ferguson HW (1995) Virulence of Flavobacterium branchiophilum in experimentally infected salmonids. J Fish Dis 18:249-262

Powell MD, Harris JO (2004) Influence of oxygen on the toxicity of chloramine-T to Atlantic salmon (Salmo salar L.) smolts in fresh and seawater. J Aquat Anim Health (in press)

Editorial responsibility: David Bruno,

Aberdeen, UK
Roberts SD, Powell MD (2003) Comparative ionic flux and gill mucous cell histochemistry: effects of salinity and disease status in Atlantic salmon (Salmo salar L.). Comp Biochem Physiol A 134:525-537

Song YL, Fryer JL, Rohovec JS (1988) Comparison of six media for the cultivation of Flexibacter columnaris. Fish Pathol 23:91-94

Stringer-Roth KM, Ynghans W, Caslake LF (2002) Differences in chondroitin AC lase activity of Flavobacterium columnare isolates. J Fish Dis 25:687-691

Thomas-Jinu S, Goodwin AE (2004) Acute columnaris infection in channel catfish, Ictalurus punctatus (Rafinesque): efficacy of practical treatments for warmwater aquaculture ponds. J Fish Dis 27:23-28

Vatos IN, Thompson KD, Adams A (2002) Development of an immunofluorescent antibody technique (IFAT) and in situ hybridization to detect Flavobacterium psychrophilum in water samples. Aquac Res 33:1087-1090

Verdouw H, van Etcheld CJA, Dekkers EM (1978) Ammonium determinations based upon indophenol formation with sodium salicylate. Water Res 12:399-402

Wakabayashi H, Hikida M, Masumura K (1986) Flexibacter maritimus sp. nov., a pathogen or marine fishes. Int J Syst Bacteriol 36:396-398

Zall DM, Fisher MD, Garner QM (1956) Photometric determination of chloride in water. Anal Chem 28:1665-1678

Submitted: March 30, 2004; Accepted: May 25, 2004

Proofs received from author(s): August 30, 2004 